\title{
EXPRESSION BY CALCULATION OF CORRELATION BETWEEN INITIAL SPEED LOSSES BY THE NUMBER OF FIRES SHOT WITH THE 76 MM, 1982 MODEL CANNON AND ITS INTERPRETATION DEPENDING ON THE PHYSICAL WEAR BY PULLING THE BARREL
}

\author{
Stelian POPESCU, Mircea VLADU, Florin ILIE \\ "Nicolae Bălcescu" Land Forces Academy, Sibiu, Romania \\ fam_popes@yahoo.com, vladumircea57@yahoo.com, \\ ilieflorinv@yahoo.com
}

\begin{abstract}
In the rifled barrels of each type of armament, the material wear of the rifled bore is closely related to the number of fires shot, this being expressed by the variation of the inner diameter of the barrel in the sections where the measurements were made and evidenced by the decreases in the initial velocity, $\left(\Delta V_{o}\right)$ relative to the number of fires shot $(N)$. As the number of fires shot increases, the initial velocity of the fired projectiles decreases. In the present paper, the regression equation of the initial velocity of the $76 \mathrm{~mm}, 1982$ model cannon was determined and it was emphasized that the differences between the initial velocity determined by the regression calculation $\left(V_{\text {oir }}\right)$ and the experimentally determined initial velocity $\left(V_{o i}\right)$ are very small. Therefore, it can be appreciated that the law of regression of the determined initial velocity reproduces faithfully the real situation of the decrease in the initial velocity when firing with this type of cannon.
\end{abstract}

Keywords: cannon, initial velocity, wear, fires, regression, experimental, physical wear

\section{Introduction}

Following the experimental firing with the $76 \mathrm{~mm}$ mountain gun 1982 model and the measurements of the barrel's diameters between fillings and voids, made in 9 sections thereof, the table with the variation of the diameter of the gun barrel'sbore was drawn up.

Experiments have been carried out within the durability of the $76 \mathrm{~mm}$ cannon, 1982 model and took place in a specialized army polygon.

The material wear of the rifled bore progressed as the number of the cannon shots increased, this being expressed by the variation of the inside diameter of the barrel in the sections where the measurements were made.
The dependence of the initial speed loss $\left(\Delta V_{o}\right)$ on the number of the cannon shots $(\mathrm{N})$ is basically known and is specific to the rifled barrel of each type of weapon. As the number of cannon shots pulled increases, the initial velocity of the fired projectiles decreases.

Knowing the initial velocity values obtained after shooting a large number of projectiles (4666 in our case) we can construct the diagram corresponding to the function $V_{o}=f(N)$, which shows how the initial speed $\left(\mathrm{V}_{\mathrm{o}}\right)$ varies, experimentally determined on the number of projectiles $(\mathrm{N})$. The graphical representation is shown in figure no. $1 \mathrm{a}$ ) and in figure no. $1 \mathrm{~b}$ ).

From the graphical representation of the variation of the initial velocity it is approximated that $V_{o}=f(N)$ is determined 
by the following law of variation:

$$
V_{\mathrm{o}}=\left\{\begin{array}{l}
398, \text { for } \mathrm{N} \leq 150 \\
\mathrm{a}+\mathrm{bN}+\mathrm{cN}^{2}+\varepsilon_{\mathrm{i}}, \text { for } \mathrm{N}>150
\end{array}\right. \text {, }
$$

where: $V_{0}-$ the initial experimentally determined velocity;

$\mathrm{N}$ - the number of shots fired according to which the initial velocity was determined;

$\mathrm{a}, \mathrm{b}, \mathrm{c}$ - the coefficients of the equation to be determined;

$\varepsilon_{\mathrm{i}}$ - the error of the method used.

According to $\mathrm{V}_{\mathrm{o}}$ variation form, in case of experimental firing, it can be appreciated that:

$\mathrm{V}_{\mathrm{o}}=\mathrm{a}+\mathrm{bN}+\mathrm{cN}^{2}+\varepsilon_{\mathrm{i}}$ represents the initial rate regression equation, and $a, b, c$ are coefficients of regression.

The regression equation in (1.1) is solved by the lowest square method which specifies that the sum of squares of errors at the limit tends to zero. Applying this method, the following equation system has to be solved to determine the coefficients a, b, c:

$$
\left\{\begin{array}{l}
a n+b \sum_{i=1}^{n} N_{i}+c \sum_{i=1}^{n} N_{i}^{2}=\sum_{i=1}^{n} V_{i} \\
a \sum_{i=1}^{n} N_{i}+b \sum_{i=1}^{n} N_{i}^{2}+c \sum_{i=1}^{n} N_{i}^{3}=\sum_{i=1}^{n} V_{o_{i}} N_{i}, \\
a \sum_{i=1}^{n} N_{i}^{2}+b \sum_{i=1}^{n} N_{i}^{3}+c \sum_{i=1}^{n} N_{i}^{4}=\sum_{i=1}^{n} V_{o_{i}} N_{i}^{2}
\end{array}\right.
$$

where: $\mathrm{n}=10$ and represents the number of initial rate determinations $\mathrm{V}_{\mathrm{o}}$.

The data obtained from the experimental firings lead to the values mentioned in table no. 1 , values based on which the system of equations (1.2) will have the form (1.3).

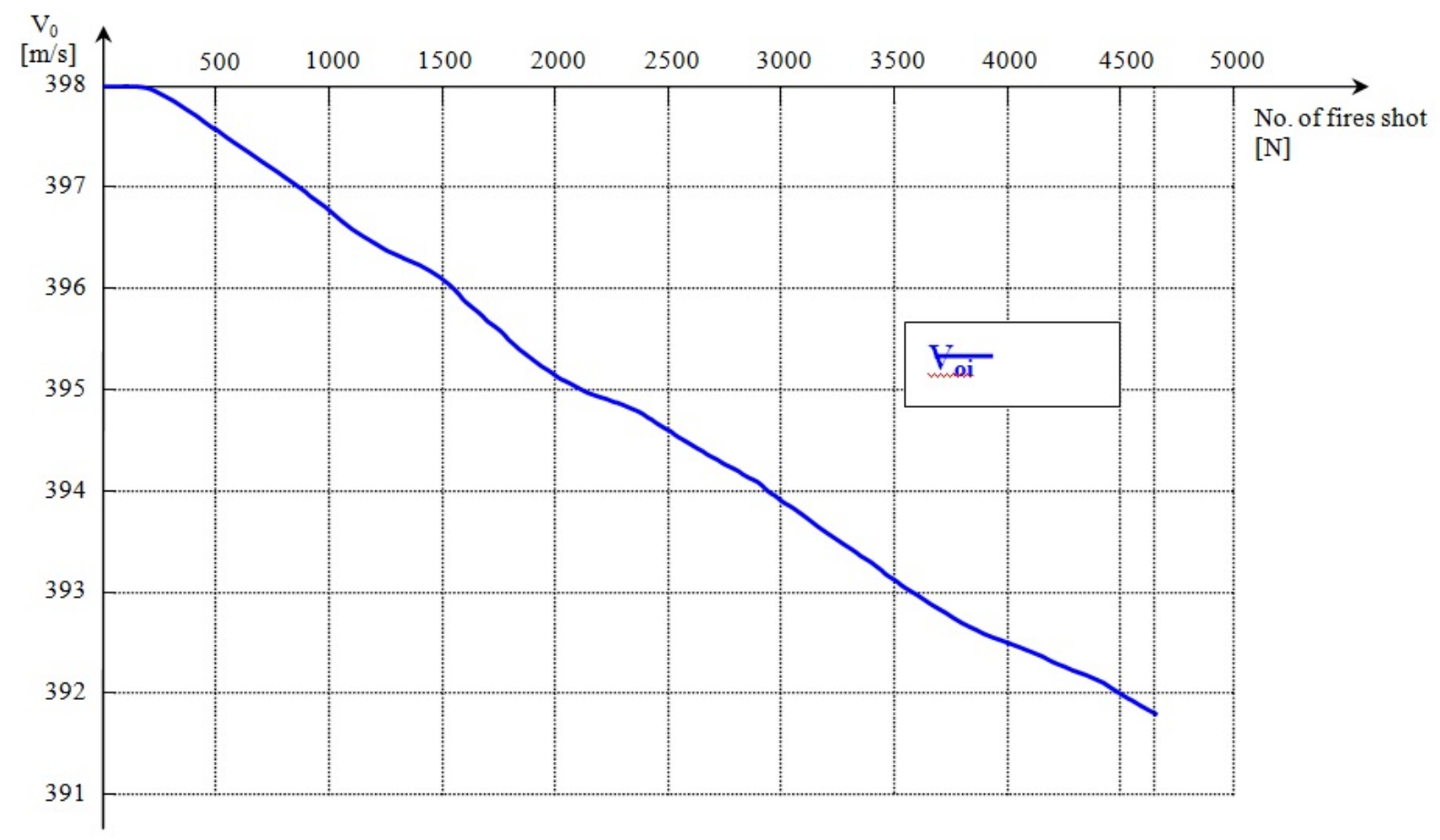

Figure no. 1a): Variation diagram of the initial velocity, according to experimental firing data, for the $76 \mathrm{~mm}$, model 1982 cannon barrel 


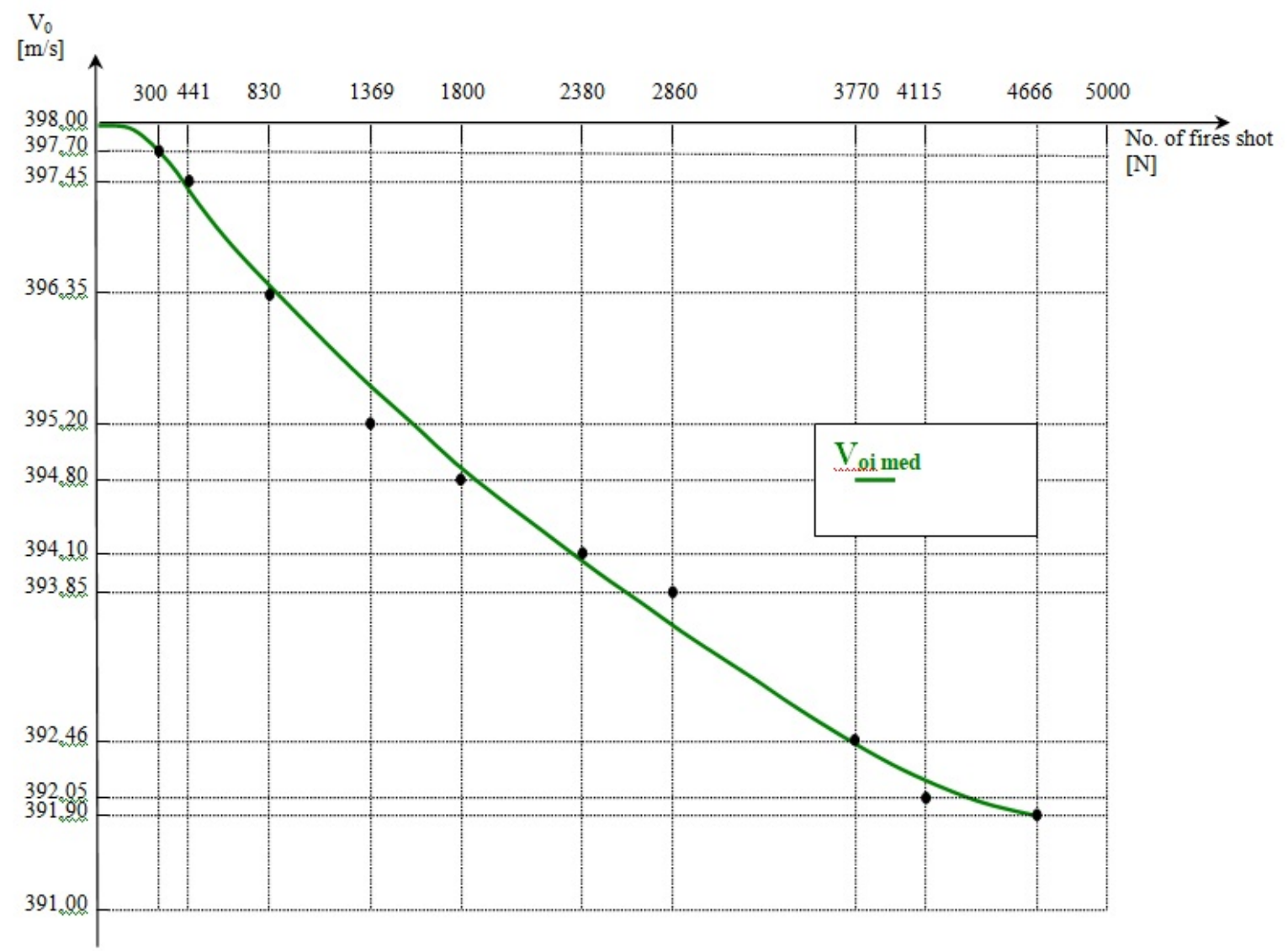

Figure no. 1b): Variation diagram of the initial velocity in relation to the number of shots fired, applying the lowest squares method, for the $76 \mathrm{~mm}$, model 1982 cannon barrel

Table no. 1

\begin{tabular}{|c|c|c|c|c|c|c|c|}
\hline $\begin{array}{c}\text { Crt. } \\
\text { no. }\end{array}$ & $\mathrm{V}_{\mathrm{oi}}$ & $\mathrm{N}_{\mathrm{i}}$ & $\mathrm{N}_{\mathrm{i}}^{2}$ & $\mathrm{~N}_{\mathrm{i}}^{3}$ & $\mathrm{~N}_{\mathrm{i}}^{4}$ & $\mathrm{~V}_{\mathrm{oi}} \cdot \mathrm{N}_{\mathrm{i}}$ & $\mathrm{V}_{\mathrm{o} \cdot \mathrm{i}^{\prime}} \mathrm{N}_{\mathrm{i}}^{2}$ \\
\hline 1 & 397,70 & 300 & 90000 & $2,7 \cdot 10^{7}$ & $8,1 \cdot 10^{9}$ & 119310 & $0,35793 \cdot 10^{8}$ \\
\hline 2 & 397,45 & 441 & 194481 & $8,5766121 \cdot 10^{7}$ & $3,7822859 \cdot 10^{10}$ & 175275,45 & $0,7729647 \cdot 10^{8}$ \\
\hline 3 & 396,35 & 830 & 688900 & $5,71787 \cdot 10^{8}$ & $4,7458321 \cdot 10^{11}$ & 328970,50 & $2,7304551 \cdot 10^{8}$ \\
\hline 4 & 395,20 & 1369 & 1874161 & $2,5657264 \cdot 10^{9}$ & $3,5124794 \cdot 10^{12}$ & 541028,80 & $7,4066842 \cdot 10^{8}$ \\
\hline 5 & 394,80 & 1800 & 3240000 & $5,832 \cdot 10^{9}$ & $1,04976 \cdot 10^{13}$ & 710640 & $1,279152 \cdot 10^{9}$ \\
\hline 6 & 394,10 & 2380 & 5664400 & $1,3481272 \cdot 10^{10}$ & $3,2085427 \cdot 10^{13}$ & 937958 & $2,23234 \cdot 10^{9}$ \\
\hline 7 & 393,85 & 2860 & 8179600 & $2,3393656 \cdot 10^{10}$ & $6,6905856 \cdot 10^{13}$ & 1126411 & $3,2215354 \cdot 10^{9}$ \\
\hline 8 & 392,46 & 3770 & 14212900 & $5,3582633 \cdot 10^{10}$ & $2,0200652 \cdot 10^{14}$ & 1479574,20 & $5,5779947 \cdot 10^{9}$ \\
\hline 9 & 392,05 & 4115 & 16933225 & $6,968022 \cdot 10^{10}$ & $2,867341 \cdot 10^{14}$ & 1613285,75 & $6,6386708 \cdot 10^{9}$ \\
\hline 10 & 391,90 & 4666 & 21771556 & $10,158608 \cdot 10^{10}$ & $4,7400065 \cdot 10^{14}$ & 1828605,40 & $8,5322727 \cdot 10^{9}$ \\
\hline$\Sigma$ & 3945,86 & 22531 & $7,2849223 \cdot 10^{7}$ & $2,7080614 \cdot 10^{11}$ & $1,0762631 \cdot 10^{15}$ & $8,861059 \cdot 10^{6}$ & $2,8608769 \cdot 10^{10}$ \\
\hline
\end{tabular}

$$
\left\{\begin{array}{c}
\mathrm{a} \cdot 10+\mathrm{b} \cdot 22531+\mathrm{c} \cdot 7,2849223 \cdot 10^{7}=3945,86 \\
\mathrm{a} \cdot 22531+\mathrm{b} \cdot 7,2849223 \cdot 10^{7}+\mathrm{c} \cdot 2,7080614 \cdot 10^{11}=8,861059 \cdot 10^{6} \\
\mathrm{a} \cdot 7,2849223 \cdot 10^{7}+\mathrm{b} \cdot 2,7080614 \cdot 10^{11}+\mathrm{c} \cdot 1,0762631 \cdot 10^{15}=2,8608769 \cdot 10^{10}
\end{array},\right.
$$


The system is solved using the determinants' method, obtaining the following values for the coefficients $a, b, c$ :

$$
\begin{aligned}
& \mathbf{a}=\left|\begin{array}{ccc}
3945,86 & 22531 & 7,2849223 \cdot 10^{7} \\
8,861059 \cdot 10^{6} & 7,2849223 \cdot 10^{7} & 2,7080614 \cdot 10^{11}
\end{array}\right| \\
& 2,8608769 \cdot 10^{10} \quad 2,7080614 \cdot 10^{11} \quad 1,0762631 \cdot 10^{15}
\end{aligned}
$$

$\begin{array}{lll}10 & 22531 & 7,2849223 \cdot 10^{7}\end{array}$

$$
=398,20792
$$$$
\begin{aligned}
& \mathrm{b}=\left|\begin{array}{ccc}
10 & 3945,86 & 7,2849223 \cdot 10^{7} \\
22531 & 8,861059 \cdot 10^{6} & 2,7080614 \cdot 10^{11} \\
7,2849223 \cdot 10^{7} & 2,8608769 \cdot 10^{10} & 1,0762631 \cdot 10^{15}
\end{array}\right| \\
& \hline \begin{array}{ccc}
22531 & 7,2849223 \cdot 10^{7} & 2,7080614 \cdot 10^{11} \\
10 & 22531 & 7,2849223 \cdot 10^{7} \\
7,2849223 \cdot 10^{7} & 2,7080614 \cdot 10^{11} & 1,0762631 \cdot 10^{15}
\end{array} \mid \\
& =-0,14548 \cdot 10^{-2}
\end{aligned}
$$

$$
V_{\text {o calculated }}=\left\{\begin{array}{l}
398, \text { for } \mathrm{N} \leq 150 \\
398,20792-0,14548 \cdot 10^{-2} \cdot \mathrm{N}+1,74067 \cdot 10^{-8} \mathrm{~N}^{2}, \text { for } \mathrm{N}>150
\end{array}\right.
$$

By successive substitutions in the number of fired shots $(\mathrm{N})$, in each of the 10 groups of partial fires of the durability test, the

$$
\begin{aligned}
& \mathrm{c}=\left|\begin{array}{ccc}
10 & 22531 & 3945,86 \\
22531 & 7,2849223 \cdot 10^{7} & 8,861059 \cdot 10^{6} \\
7,2849223 \cdot 10^{7} & 2,7080614 \cdot 10^{11} & 2,8608769 \cdot 10^{10}
\end{array}\right| \\
& \begin{array}{ccc}
10 & 22531 & 7,2849223 \cdot 10^{7} \\
22531 & 7,2849223 \cdot 10^{7} & 2,7080614 \cdot 10^{11} \\
7,2849223 \cdot 10^{7} & 2,7080614 \cdot 10^{11} & 1,0762631 \cdot 10^{15}
\end{array} \mid
\end{aligned}
$$

Thus, the velocity regression equation will look like:

$V_{\text {oir }}=398,20792-0,14548 \cdot 10^{-2} \cdot \mathrm{N}+$

$$
1,74067 \cdot 10^{-8} \cdot \mathrm{N}^{2}
$$

where:

$\mathrm{V}_{\text {oir }}$ - represents the initial velocity calculated according to the regression equation, and the calculated initial velocity will be represented by the following law: corresponding values for $\mathrm{V}_{\text {oir }}$ and the differences $\mathrm{V}_{\text {oir }}-\mathrm{V}_{\text {oi }}$ are given in table no. 2:

\begin{tabular}{|c|r|r|r|r|}
\hline $\begin{array}{c}\text { Crt. } \\
\text { no. }\end{array}$ & \multicolumn{1}{c|}{$\mathbf{N}_{\mathbf{i}}$} & $\mathbf{V}_{\mathbf{o i}}$ & $\mathbf{V}_{\text {oir }}$ & $\mathbf{V}_{\text {oir }}-\mathbf{V}_{\mathbf{~ o i}}$ \\
\hline 1 & 300 & 397,70 & 397,77 & 0,07 \\
\hline 2 & 441 & 397,45 & 397,56 & 0,11 \\
\hline 3 & 830 & 396,35 & 397,01 & 0,66 \\
\hline 4 & 1369 & 395,20 & 396,24 & 1,04 \\
\hline 5 & 1800 & 394,80 & 395,64 & 0,84 \\
\hline 6 & 2380 & 394,10 & 394,84 & 0,74 \\
\hline 7 & 2860 & 393,85 & 394,14 & 0,29 \\
\hline 8 & 3770 & 392,46 & 392,97 & 0,51 \\
\hline 9 & 4115 & 392,05 & 392,51 & 0,46 \\
\hline 10 & 4666 & 391,90 & 391,78 & $-0,12$ \\
\hline$\Sigma$ & 22531 & 3945,86 & 3950,46 & \\
\hline
\end{tabular}

According to the values shown in the table, it can be observed that the differences between the initial velocity determined by the regression calculation $\left(\mathrm{V}_{\text {oir }}\right)$ and the experimentally determined initial velocity $\left(\mathrm{V}_{\mathrm{oi}}\right)$ are very small. Therefore, it can be appreciated that the law of regression of the

Table no. 2

initial velocity determined according to (1.4) faithfully reproduces the real situation of decreasing the initial velocity when firing with the $76 \mathrm{~mm}, 1982$ model cannon, as can be seen from figure no. 2 a) and figure no. $2 \mathrm{~b}$ ). 


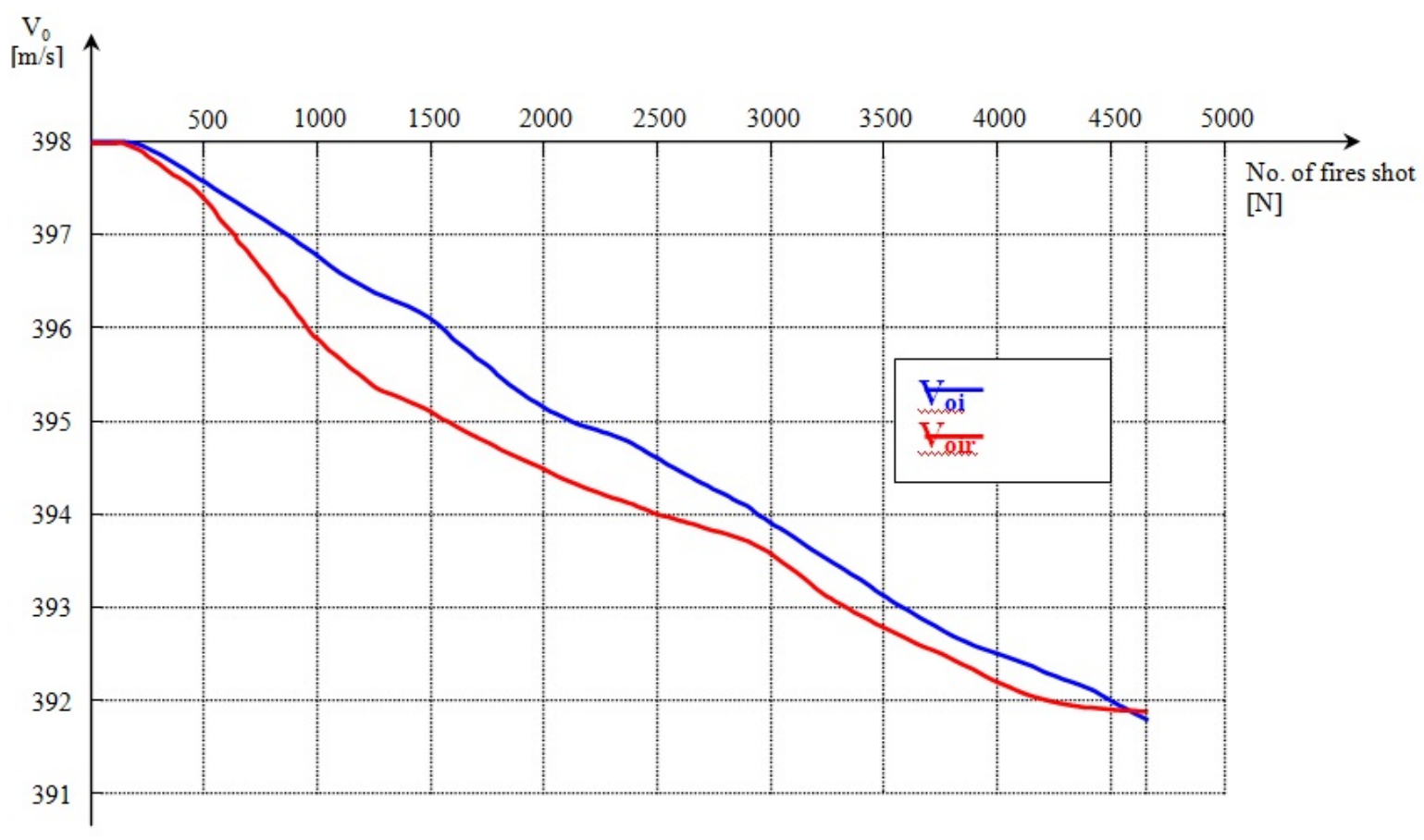

Figure no. 2a): Comparative chart of variation of the initial velocity, according to the experimental firing data and the regression equation of the $76 \mathrm{~mm}$, model 1982 cannon barrel

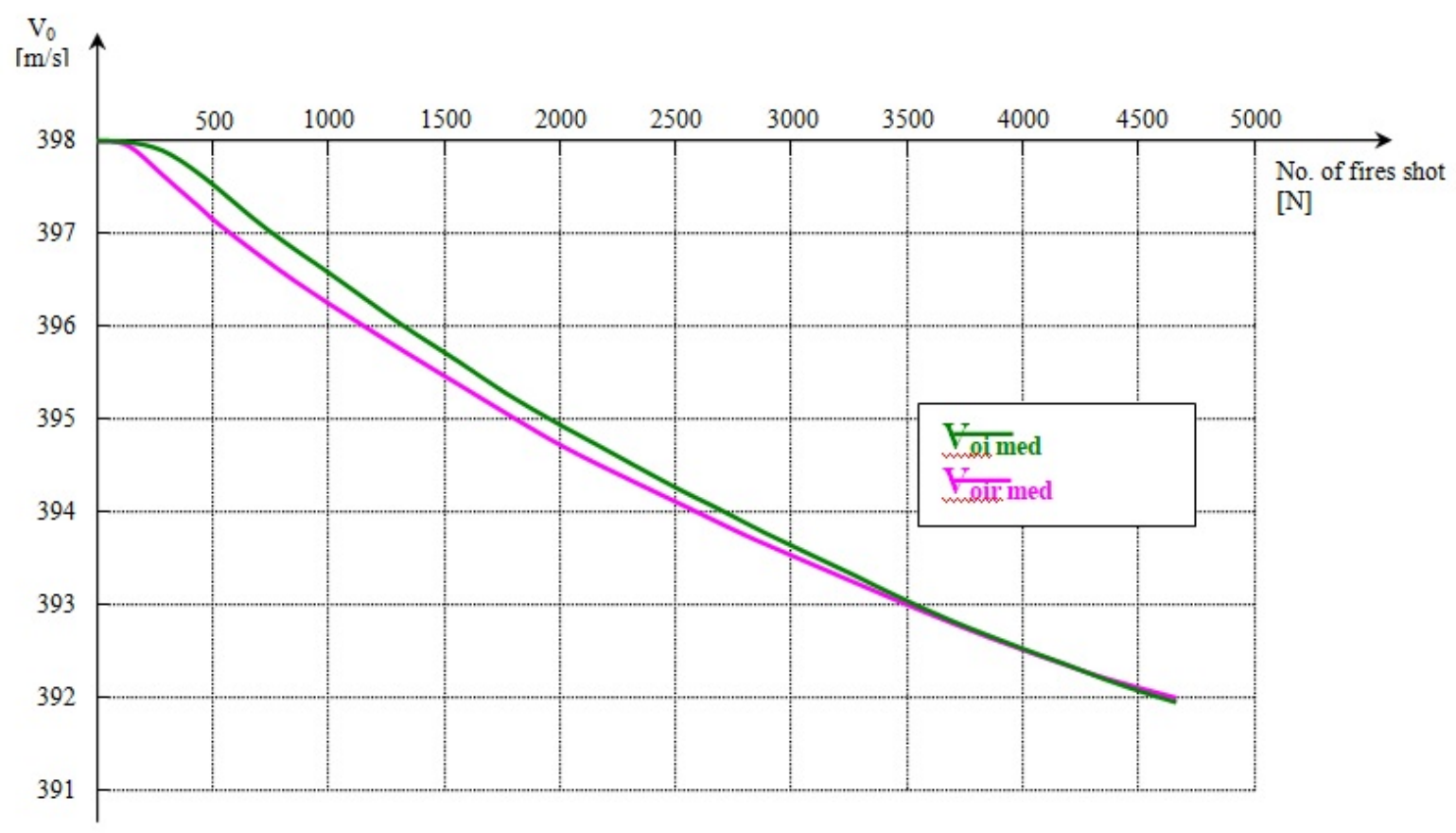

Figure no. 2b): Comparative chart of variation of the initial velocity in relation to the number of fires shot and the regression law, applying the lowest squares method, for the $76 \mathrm{~mm}$, model 1982 cannon barrel

In practice, the decrease of the initial velocity as the number of fires shot with a barrel's muzzle means increasing the physical wear of the rifled bore. 
Comparing the results of measurements, between fillings and voids, executed at the $76 \mathrm{~mm}, 1982$ model cannon, it is noted that as the number of fires increased, the phenomenon of wear is also accentuated. However, the phenomenon is not so obvious from a series of fires hot to another as a result of the transfer of materials that takes place between the projectile's bore base housing and the main bore during the translation and rotation movements of the projectile in the barrel. For this reason, it is necessary that, after a relatively large number of fires shot, the barrel is subject to the process of bore brushing to eliminate led.

The method of calculating the initial velocity using the regression equation can be used to manufacture the weapon where it is required to periodically check it through a durability test for the pulling of the barrel, requiring high ammunition consumption and thus time and high costs.

Moreover, when using the barrels of the respective caliber, the method will be used to assess the initial velocity, without the need for special firing, and the remaining battle capacity of the barrel at a given moment, expressed by the number of fires it can still shoot efficiently.

\section{Conclusions}

- The physical wear of the barrel muzzles resulting from the fires is an inevitable and irreversible process, which ultimately leads to their removal from usage. Wear control and its reduction is a permanent concern of the military system, the current technical possibilities allowing for the reduction of the phenomenon, respectively increasing the firing durability of the armament barrels5 to 10 times;

- The processes of wear of the inner surface of the barrels' muzzle are a result of the interaction between the three ballistic elements that compete with the firing phenomenon: the propeller, the projectile, the barrel, the support parameter of the processes taking place in the barrels being the temperature;

- It is easy to see the direct link that exists between increasing the wear of the weapon barrels used to shoot as the number of fires shot increased. To highlight the phenomenon, a calculation method was determined, with application to the $76 \mathrm{~mm}, 1982$ model cannon barrel on the assessment of initial velocity loss based on the number of fires shot and the interpretation in relation to barrel's wear. The calculation method uses a statistical model.

- The calculation method faithfully reproduces the real situation of decreasing the initial velocity when firing a large number of shots due to the worsening of the wear phenomenon.

\section{References}

[1] Ioan Pană, Contribuţii privind reducerea uzurii ţevilor armamentului clasic, Bucureşti, 1985.

[2] Popa Gh. Ioan, Construcţia şi exploatarea gurilor de foc de artilerie, Editura Academiei Militare, Bucureşti, 1974.

[3] Popescu, St.; Dascălu, V., Tendinţe şi realizări constructive în dezvoltarea gurilor de foc de artilerie modern, Sesiunea de Comunicări Ştiinţifice, Academia Forţelor Terestre „Nicolae Bălcescu”, Sibiu, 2002.

[4] Traian, B., Tehnologia reparării armamentului şi muniţiilor, Academia Militară, Bucureşti, 1975.

[5] Stelian POPESCU, Evaluarea resursei tehnice a gurilor de foc de artilerie de calibre mijlocii și mari, Editura Academiei Forțelor Terestre "Nicolae Bălcescu”, Sibiu, 2015. 